\title{
"Employment Generation and Poverty Alleviation in Developing Countries" Challenges and Opportunitiesspecial Reference to India
}

\author{
${ }^{1}$ Shubhendu S. Shukla, ${ }^{2}$ Ashutosh Mishra \\ ${ }^{1,2}$ SR Group Of Institutions, Lucknow
}

\begin{abstract}
Implications of economic policies initiated and pursued by the Government for the creation of gainful employment opportunities. After independence, when India initiated the programme of economic development through planning mechanism, neither of the two prevalent economic theories i.e. the Keynesian theory of effective demand and the neo-classical theory of flexible wage rates was not found suitable to the Indian conditions.

Poverty reduction has been an important goal of development policy since the inception of planning in India. Various antipoverty, employment generation and basic services programmes have been in operation for decades in India. The ongoing reforms attach great importance to removal of poverty, and addressing specifically the wide variations across States and the rural-urban divide. Anti-poverty strategy has three broad components: promotion of economic growth; promotion of human development; and targeted programmes of poverty alleviation to address multi-dimensional nature of poverty. The various programmes targeted at the poor have been streamlined and strengthened in recent years, including through the NREGS.

The influence of macro economic environment on the industry speeds ahead economy generates more jobs and higher levels of wages and income through increasing productivity. To achieve these objectives, series of outward oriented policy changes i.e. industrial reforms, fiscal reforms, monetary reforms, trade policy reform etc. were introduced. An economic reform has been evolving historically and being propelled forward with incredible speed by the technological revolution.
\end{abstract}

Submitted date 07 June 2013

Accepted Date: 15 June 2013

\section{Introduction}

The present paper looks at the employment challenges faced by India within the framework of "ten core elements" identified by the Global Employment Agenda of the ILO (International Labour Organization). These elements relate to trade and investment, technological change, sustainable livelihoods, macro policy, entrepreneurship development, skills development, active labour market policies, social protection, conditions of work and poverty reduction.

Following are the 'ten core elements' of the Agenda, the first four addressing the economic environment and the last six the labour market:

1. Promoting trade and investment for productive employment and market access for developing countries.

2. Promoting technological change for higher productivity and job creation and improved standard of living.

3. Promoting sustainable development for sustainable livelihoods.

4. Macro-economic policy for growth and employment: a call for policy integration.

5. Promoting decent employment and entrepreneurship.

6. Employability by improving knowledge and skills.

7. Active labour market policies for employment, security in change, equity and poverty reduction.

8. Social protection as a productive factor.

9. Occupational safety and health: synergies between security and productivity.

10. Productive employment for poverty reduction and development.

Employment generation has been one of the important objectives of development planning in India. The problem of employment is closely interlinked with the eradication of poverty. There are three main aspects of the employment problem in India. They are the problem of proportion of labour to total population, problem of productivity of labour and problem of unemployment and underemployment of labour. These three aspects are interrelated. There is low rate participation of labour in India. Low rate of employment among women is a striking feature in India. There has almost been no change in LFPR (Labour Force Participation Rate). The dependency rate is quite high in India. Problem of unemployment and underemployment is the chronic feature of the Indian economy. It is the main cause of poverty in India. Unemployment in India is mostly structural. The rate of unemployment is different in different states. Sector wise unemployment in India is rural and urban unemployment. 
Urban unemployment is of two types viz, industrial unemployment and educated unemployment. Rural unemployment is more than $70 \%$ as rural population is more than $70 \%$ of the total population in India. There are various types of unemployment in India. They are seasonal, structural, frictional, technological, involuntary and disguised. The productivity criterion refers to disguised unemployment. It is mainly found in agriculture. It is a kind of underemployment. It involves both zero marginal productivity of man hour and zero marginal productivity of labour. It implies too many persons on too little land. Educated unemployment is one variant of open unemployment. It is mainly due to the defective educational system. Underemployment is one variant of open unemployment.

It is mainly due to the defective educational system. Underemployment may be visible or invisible. The ratio between unemployed workers and total labour force is called unemployment rate. Low productivity of employment is the third aspect of the employment problem. Productivity of labour in India is low due to many factors. The essential of the employment policy is to increase production, control population growth, reform the education system, emphasize cottage and small scale industrial units to tackle the problem of seasonal, frictional, structural, technological and disguised unemployment and effectively do manpower planning etc. There have been various schemes to solve the problem of educated unemployment.

\section{Anti-Poverty, Employment Generation and Basic Services Programmes} (A) Pradhan Mantri Gram Sadak Yojana (Pmgsy)

Launched in December 2000 as a 100 per cent CSS, PMGSY aims to provide all-weather connectivity to all the eligible unconnected rural habitations. Bharat Nirman, envisages connectivity by 2009 to all the habitations with a population of 1000 or more in the plains, and of 500 or more in the hilly, desert and tribal areas. The systematic upgradation of the existing rural road network also is an integral component of the scheme, funded mainly from the accruals of diesel cess in the Central Road Fund, with support of the multilateral funding agencies and the domestic financial institutions. Up to December 2005, with an expenditure of Rs.12,049 crore, a total length of $82,718 \mathrm{~km}$. of road works had been completed. .

\section{(B) Indira Awaas Yojana (Iay)}

IAY aims to provide dwelling units, free of cost, to the Scheduled Castes (SCs), Scheduled Tribes (STs), and freed bonded labourers, and also the non-SC/ST BPL families in rural areas. It is funded on a costsharing basis in the rates of 75.25 between the Centre and the States. Under IAY, the ceiling on construction assistance is Rs.25,000/- per unit in the plains and Rs.27,500/- for hilly/difficult areas; and Rs. 12,500/- on upgradation of unserviceable kutcha house to pucca/semi pucca house for all areas. Up to January 30, 2006, about 138 lakh houses had been constructed/upgraded with an expenditure of Rs.25,208 crore.

\section{(C) Swarnjayanti Gram Swarozgar Yojana (Sgsy)}

SGSY, launched in April, 1999 after restructuring the Integrated Rural Development Programme and allied schemes, is the only self-employment programme for the rural poor. The objective is to bring the selfemployed above the poverty line by providing them income-generating assets through bank credit and Government subsidy. Up to November 2005, the Centre and States, sharing the costs on 75:25 basis, had allocated Rs.8,067 crore, of which Rs. 6,980 crore had been utilized to assist 62.75 lakh self-employed.

\section{(D) Sampoorna Grameen Rozgar Yojana (Sgry)}

SGRY, launched on September 25, 2001 to provide additional wage employment in the rural areas, has a cash and food grains component, and the Centre bears 75 per cent and 100 per cent of the cost of the two with the balance borne by the States/UTs. In 2004-05, 82.23 crore persondays were generated with the Centre releasing Rs. 4,496 crore as cash component and about 50 lakh tonnes of foodgrains to the States/ UTs. Besides, under the special component of the SGRY, with the States/UTs meeting the cash components, Centre released 26 lakh tonnes of foodgrains to the 13 calamity affected States. In 2005-06 up to November, 2005, the number of persondays generated under SGRY was 48.75 crore, while the Centre's contributions in terms of the cash and foodgrains components up to January, 2006 were Rs. 4651 crore and 35 lakh tonnes, respectively. Under the special component, about 11.65 lakh tonnes of foodgrains have been released to the 11 calamity-hit States in the current year

\section{(E) National Food For Work Programme (Nffwp)}

The NFFWP was launched as a CSS in November 2004 in the 150 most backward districts to generate additional supplementary wage employment with food security. States receive food grains under NFFWP free of cost. The focus of the programme is on works relating to water conservation, drought proofing (including aforestation /tree plantation), land development, flood-control/protection (including drainage in waterlogged areas), and rural connectivity in terms of all-weather roads. In 2004-05, allocation of Rs 2,020 crore and 20 lakh 
tonnes of foodgrains generated 7.85 crore persondays of employment. In 2005-06, of the allocation of Rs 4,500 crore and 15 lakh tonnes of food grains (Revised), Rs.2,219 crore and 11.58 lakh metric tonnes of foodgrains had been released up to January 27, 2006. About 17.03 lakh persondays were generated up to December 2005.

\section{(F) Dpap, Ddp And Iwdp}

Drought Prone Areas Programme (DPAP) was launched in 1973-74 to tackle the special problems faced by those areas constantly affected by severe drought conditions. Desert Development Programme (DDP) was launched in 1977-78 to mitigate the adverse effects of desertification. Integrated Wastelands Development Programme (IWDP) has been under implementation since 1989-90 for the development of wastelands/ degraded lands. The basis of implementation has been shifted from sectoral to watershed basis from April 1995. For 200506, Rs. 353 crore, Rs. 268 crore and Rs. 485 crore have been allocated for DPAP, DDP and IWDP, respectively. So far in 2005-06 up to October, 2005, 3000 new projects covering 15 lakh ha., 2000 new projects covering 10 lakh ha. and 340 new projects covering 16 lakh ha. have been sanctioned under DPAP, DDP and IWDP, respectively.

\section{(G) Swarna Jayanti Shahari Rozgar Yojana (Sjsry)}

In December 1997, the Urban Self-Employment Programme (USEP) and the Urban Wage Employment Programme (UWEP), which are the two special components of the SJSRY, substituted for various programmes operated earlier for urban poverty alleviation. The SJSRY is funded on a 75:25 basis between the Centre and the States. In 2003-04, the central allocation of Rs. 94.50 crore plus Rs. 10.50 crore for North- Eastern Region including Sikkim was fully utilized. Even 2004-05 saw the release of the entire budgetary allocation of Rs. 122.00 crore. In 2005-06, out of an allocation of Rs. 160.00 crore, Rs. 84.52 crore had been utilized until November 30, 2005.

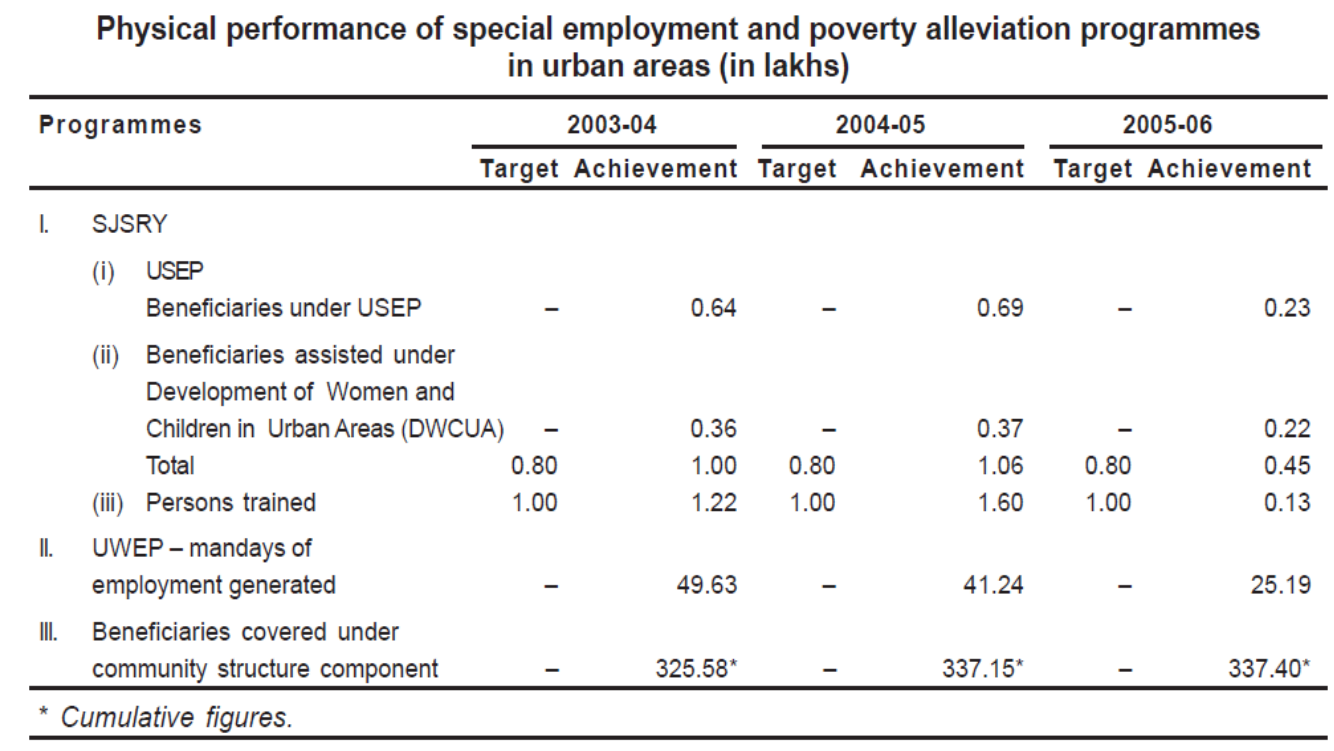

\section{(H) Valmiki Ambedkar Awas Yojana (Vambay)}

VAMBAY, launched in December 2001, facilitates the construction and up-gradation of dwelling units for the slum dwellers, and provides a healthy and enabling urban environment through community toilets under Nirmal Bharat Abhiyan, a component of the Scheme. The Central Government provides a subsidy of 50 per cent, with the balance provided by the State Government. Since its inception and up-to December, 31 2005, Rs. 866.16 crore had been released as Central subsidy for the construction/upgradation of 4,11,478 dwelling units and 64,247 toilet seats under the Scheme. For 2005-06, out of the tentative Central allocation of Rs. 249 crore, up to December 31, 2005, an amount of Rs.96.4 crore had been released covering 60,335 dwelling units and 381 toilet seats.

\section{The Employment Scenario}

Indian economic development under different plan periods the rate of growth of output has never been integrated with the rate of growth of employment. Accelerated economic growth has always been found to be favourite with the Indian planners. From the very first plan this concept of economic growth was very much interlinked with the increase in the employment opportunity, reduction of income inequality and poverty through there was an initial debate whether reduction of income inequality was conducive to growth or not. It 
was posed that reduction in income inequality would retard savings and hence capital formation in the LDCs, which would slacken economic growth.

\begin{tabular}{|l|l|l|}
\hline Plans & $\begin{array}{l}\text { Annual GDP Growth Rate } \\
\text { (at constant price) }\end{array}$ & Growth of Employment \\
\hline First Plan (1951-56) & 3.7 & 0.39 \\
\hline Second Plan (1956-61) & 4.2 & 0.87 \\
\hline Third Plan (1961-66) & -3.8 & 2.03 \\
\hline Fourth Plan (1969-74) & 3.4 & 1.99 \\
\hline Fifth Plan (1974-78) & 5.0 & 1.84 \\
\hline Sixth Plan (1980-85) & 5.5 & 1.89 \\
\hline Seventh Plan (1985-90) & 3.6 & 1.26 \\
\hline Eight Plan (1991-96) & 6.7 & 1.86 \\
\hline Ninth Plan (1997-2002) & 7.7 & 1.14 \\
\hline Tenth Plan (2002-2007) & 7.2 & 1.23 \\
\hline Eleven Plan (2007-2012) & $7.5^{*}$ & $1.82^{*}$ \\
\hline
\end{tabular}

Source: Plan Documents (* Approximate)

\section{Growth Of Employment By Sector}

The employment generation in sartorial base i.e. primary, secondary and tertiary sectors it is fined that in pre reform and reform period the attitude of employment opportunity is in increasing trend. Following table indicate the growth of employment in sartorial base

\begin{tabular}{|l|l|l|l|l|}
\hline \multirow{2}{*}{ Economic Sector } & \multicolumn{4}{l|}{ Employment Generated in Million } \\
\cline { 2 - 5 } & $\mathbf{1 9 8 3}$ & $\mathbf{1 9 9 3}$ & $\mathbf{2 0 0 0}$ & $\mathbf{2 0 1 0}$ \\
\hline Primary Sector & $208.99(69.0)$ & $245.16(65.5)$ & $239.83(60.4)$ & $228.43(55.07)$ \\
\hline Secondary sector & $41.66(13.8)$ & $55.53(14.8)$ & $66.91(16.8)$ & $78.12(18.82)$ \\
\hline Tertiary sector & $52.11(17.2)$ & $73.76(19.7)$ & $90.26(22.7)$ & $108.35(26.11)$ \\
\hline Total Employment & $302.76(100)$ & $374.45(100)$ & $397.0(100)$ & $414.90(100)$ \\
\hline
\end{tabular}

Source: Compiled and computed form the data provided by the Planning Commission Report to Task Force on Employment

The growth rates of unemployment and labour force derived from NSS data are given in the above table, the following points emerge.

1. The growth rate of employment declined from $69 \%$ to $55.07 \%$ in agriculture, mining and other production unit in primary sector.

2. Indian economy known as rural and agro-based economy. Majority population stayed rural India, but the employment opportunities is declined by $14.03 \%$. It affects to decline purchasing power parity, compulsory mobility toward urban sector etc.

3. Secondary sector witnessed an employment growth from $13.8 \%$ to $18.82 \%$. It is an indication of development theory regarding transfer population from primary sector to secondary sector.

4. In the tertiary sector the growth rate of employment was high. It increase $17.2 \%$ to $26.11 \%$, the growth rate is near about ten per cent.

5. Employment opportunities were increase in the reform period i.e. 112 million new jobs increase last twenty years.

\section{Unemployment Rate- Urban And Rural Differences}

Rural areas. As against an unemployment rate of 10.3 per cent in 1977 in urban areas, the rural unemployment rate was 7.7 per cent. There was a significant fall in the rural unemployment rate in 1990 to 5.3 per cent, but the urban unemployment rate was of the order of 9.4 per cent, significantly higher because Indian economy was in saviour economic crisis. After the period of reform, rural unemployment rate again increased to 7.2 per cent in the year 2000 and again 8.1 per cent in 2010 while urban unemployment also marginally increased to 7.7 per cent in the year 2000 and again decrease to 7.9 per cent in 2010 . Following table indicate the unemployment among Urban and Rural sector.

Unemployment among Urban and Rural sector (As per cent of labour force)

\begin{tabular}{|l|l|l|}
\hline Period & Rural Areas & Urban Areas \\
\hline 1977 & 7.7 & 10.3 \\
\hline 1990 & 5.3 & 9.4 \\
\hline 2000 & 7.2 & 8.1 \\
\hline 2010 & 7.7 & 7.9 \\
\hline
\end{tabular}




\section{Remedial Measures}

The objectives of the economic reforms in India are broader since they aim at the overall economic development of the country through the growth of industrial and agricultural sectors. During the post reform period, despite economic growth there is low labour absorption in the Indian economy. Now there is need to evolve a multistage strategy to generate more and more employment opportunities. Following are the some of the measures, which may be included in this strategy.

- Employment generation should be the single most important criteria for investment policy, although profits and technological updating to be given due weightage.

- Constitutional obligation ensuring "Right to Work" should be the function of economic planning.

- Land reform, as an indispensable instrument for promoting distributive justice, for the employment of the poor and enhancing agricultural productivity.

- $\quad$ Rising of the domestic savings and generation of the domestic resources for investment. Foreign investment could be used as a supplement provided, "it goes where we want and not where it wants to go".

- Economic reform does not mean that Government should neglect social sectors. There is need to increase investment in social sectors, health, social security and education.

- There is need to rethink and reformulate economic policies. The private sector has to be more humane and the public sector more cost efficient. The operation of the market mechanism in a labour surplus economy shall hardly be able to humanize the private sector.

- The Government get, money through disinvestments of PSE shares, it is quite appropriate that the money should be used to develop new and viable industrial units, and this money should not be used to finance budget deficits or any other Government expenditures.

\section{Challenges In Employment Generation}

- Corruption : Corruption in employment generation agencies as well as in government system, affect badly the employment possibilities, specially in rural areas. Although this factor can't be reduce automatically by a common man, but it can be reduce by implementing the transparency in the system and automation in the system such as schemes like $e$-district, e-Governance, RTI etc.

- There is a huge gap between policy making (planning) and implementation phase of the employment generation scheme.

- Political rivalry : Every government make new and better policy still every new scheme become fail due to political rivalry in political system. Every new Govt. either close the employment program launched by previous Govt. or manipulate the program's guidelines or sometimes stop the fund for the program, which makes it difficult for unemployed to get the job availability easily. This is a great factor influencing the employment programs.

- Illiteracy : Illiteracy is playing a vital role in unemployment specially in under-developed countries like India. People even now after 60 years of independence, unaware about the schemes the Govt. is running for the employment generation. This factor can be reduced by running awareness camp and programs parallel to the employment programs.

- Reservation / Quota (Castism) : India is a democratic country so here every Govt. provide the benefits like employment and other employment related benefits to his caste person.

- Role of Private Companies : Private companies play a vital role in the employment generation in any country, but in India private companies are not functioning properly because of Govt. policies specially State Govt. Companies are not investing according to his efficiency in any of the state, specially in BIMARU States (BIhar, MAharastra, Rajasthan, Utter Pradesh) because the State Govt. is not making policies which can attract the private companies, even States like West Bengal creating problems to private players (TATA - Singure Plant) which distract the private players from the States, ultimately affect the employment generation.

\section{Opportunities In Employment Generation}

- Huge work force : India is second largest country in the world in population after China, it means we have a ample of work force and if this work force can be utilized accordingly, India can be top of the world. This huge work force is attracting the developed countries for the hiring, outsourcing and for third party work. Only the Indian Govt. have to do to train this work force according to the demand of the technology and advancement of the third world countries.

- Transparency in the system : In India now Govt understand that the people are now become technology savvy and they adopt the new technology very soon and efficiently, so Govt is implementing the eGovernance programs with every of the program through RTI Act. 
- Economical work force : Indian work force is very economical if it compare with any of the European country. The average wage in India is about $100 \mathrm{Rs}^{* *}(2.00 \$$ approx) where as in Europe it is about 10.00 $€^{* *}$ (700 Rs.) and in US it is about \$12.00** (600 Rs) which mean Indian labour is ready to work on less price as compare to European and American market, which attract the European and American player to enter in the Indian market for the economical work.

(**source : Compiled and computed data provided by the Planning Commission Report to Task Force on Employment Wages, Report of Statistical Survey of India)

- Liberalization in Exchange Policies : The Govt has liberalized the exchange and regulation act which makes it easy to enter in the Indian market for investment upto 100\% in many sectors. This is a indirect factor which will affect the employment factor in development point of view. Entry of new player like WalMart will not only develop the infrastructure but also create job opportunities for the educated persons in large prospective, although it is a political issue.

\section{References}

[1]. Anker, Richard, Chernyshev I, Egger P, Mehran F and Pitter, J.A. 2003., 'Measuring decent work with statistical indicators' in International Labour Review, Vol 142, No. 2, (Geneva, ILO).

[2]. Bhat, A K. 1994. 'Dangerous Work' in The Hindu Survey of Environment, The Hindu Group of Publications, Chennai.

[3]. Bhattacharjea, Aditya. 2006, 'Labour market regulation and industrial, performance: A critical review of empirical evidence' in The Indian Journal of Labour Economics, Vol. 49, No.2, April-June. (New Delhi, Indian Society of Labour Economics (ISLE)).

[4]. Bescond, D, Chataignier A and Mehran, F. 2003. 'Seven indicators to measure decent work' in International Labour Review, Vol 142, No. 2 (Geneva, ILO).

[5]. Besley, T and Bergess, R. 2004. 'Can regulation hinder economic performance? Evidence from India' in Quarterly Journal of Economics, Vol. 119, No.1 (Cambridge, Mass, MIT Press for Harvard University).

[6]. Chadha, G. K. 2004. 'What dominates the Indian labour market: Peacock's feathers or feet?' in The Indian Journal of Labour Economics, Vol. 47, No. 1, January-March (New Delhi, ISLE).

[7]. Chandra, Ashoka. 2003. Vocational Training in India (mimeo), October 17. (New Delhi, International Management Institute).

[8]. Ahluwalia, Isher \& Little I.M.D. (2000), India's Economic Reforms and Development, Oxford University Press.

[9]. Dutt, Ruddar (2003), Second Generation Economic Reforms in India, Deep \& Deep Publications Pvt. Ltd.

[10]. Datt, Ruddar \& K.P.M. Sundharam, (2011), Indian Economy, S.Chand \& Company Ltd, New Delhi.

[11]. Eleventh (Five Year) Plan Document, Government of India

[12]. Government of India (2005-06), Economic Survey, Ministry of Finance, Economic Division, New Delhi.

[13]. IEA 84 Conference Volumes 2001.

[14]. K. K. Bagchi, (2007), Employment and Poverty Alleviation Programmes in India, Abhijeet Publications Delhi.

[15]. N. N. Ojha (2006), Problems of Unemployment in India, A division of Chronicle Publication Pvt. Ltd. New Delhi.

[16]. Planning Commission (2004), Report to Task Force on Employment Opportunities.

[17]. Government of India-Ministry of Finance (GOI-MoF). 2007. Economic Survey, 2006-07, (New Delhi).

[18]. Government of India-Ministry of Human Resource Development (GOI-MoHRD). 2007. Selected Educational Statistics $2004-2005$. (New Delhi).

[19]. NSSO, Employment-Unemployment Situation in India (Various rounds), Ministry of Statistics and Programme Implementation (New Delhi, GoI)

[20]. NSSO, Level and Pattern of Consumer expenditure in India (Various rounds), Ministry of Statistics and Programme Implementation (New Delhi, GoI)

[21]. NSSO (2006), Employment-Unemployment Situation in India, 2004-05, Round 61st, Report No. 515, Ministry of Statistics and Programme Implementation (New Delhi, GoI)

\section{Author's profile}

Author (Shubhendu S. Shukla), has completed his MA (Economics) in 2005 and MBA in 2007, and M.Phil (Management) in 2009. He has done Post Graduated Diploma in Computer Applications from IGNOU and Post Graduated Diploma in International Business from Annamalai University.

He has worked with a prominent IT Company (Wipro Technologies) as Project Manager for $e$ Governance that was a Central Govt. Project about e-District, during his job he was responsible for Dealing with Consultant (Wipro), dealing with Techno team i.e. Trainer and other staff, he also Co-ordinate with District Administrative staff for monitoring, reporting, and his proposals and finally developed the Study materials.

Author has more than 5 years of experience in academics as he is currently working as Assistant Professor in SRM Business School, Lucknow. With the academics author has publish 5 International Research Paper, 5 National Research Papers, attended 7 National Conferences and Seminars, 2 International Seminars. Apart from SRM Business School, he is Guest and Visiting Faculty of Study Centers of Global Open University Nagaland, Karnataka State Open University, Sikkim Manipal University.

Author has taught variety of subjects as Marketing Management, Sales and Distribution, Production and Operation management, Computer Application in Management, System Analysis \& Design and Software Engineering, Database Management System, Electronic Commerce (Specialized subjects of Information Technology). 